\title{
Role of Audit and Governance Committee for internal Shariah audit effectiveness in Islamic banks
}

\author{
Azam Abdelhakeem Khalid \\ Department of Accounting and Finance, Universiti Pendidikan Sultan Idris, \\ Tanjung Malim, Malaysia
}

\begin{abstract}
Purpose - The purpose of this study is to explore the role of Audit and Governance Committee (AGC) for internal Shariah auditing's effectiveness in Bahrain's Islamic banks.

Design/methodology/approach - This paper employed two-stage approach, i.e. collecting and analysis of data. In this paper, the interviews and literature review on AGC and internal Shariah auditor were conducted as these respondents are considered vital to Islamic banks.

Findings - This paper posited that in building internal Shariah audit effectiveness' conceptual framework, the Islamic worldview theory may be employed as the theoretical foundation. Based on the theory, it was suggested that the Islamic bank's auditors and governance committees may enhance the internal Shariah auditors' effectiveness.

Practical implications - In view of the roles of AGC on internal Shariah audit effectiveness, the current exploratory research contribute to enhance the limited knowledge about AGC by describing the practices of Bahraini Islamic banks in terms of composition, roles/duties and responsibilities and operations. This study also adds to the body literature of AGC effectiveness by identifying roles, duties and responsibilities of characterizing more active AGC and suggesting that these AGC could have a positive impact on internal Shariah audit effectiveness in Bahraini Islamic banks. Overall, this paper provides important insights for Board of Director's member can refer to AGC roles, duties and responsibilities to conduct a self-diagnosis of current practice.
\end{abstract}

Originality/value - This paper uniquely seized Islamic world view for Islamic banks' AGC.

Keywords Internal Shariah audit effectiveness, Audit and Governance Committee, Islamic worldview, Islamic banks

Paper type Research paper

\section{Introduction}

The collapse of big companies like WorldCom and Enron has resulted in the emphasis on internal audit. Hence, creating an increase in the demand for internal Shariah auditors for their supervisory role. Consequently, this has resulted in the requirement of investment in internal auditing by Islamic banks, and improvement in the freedom of these auditors in ensuring the attainment of organizational goals (Rahman, 2011). Internal auditors are becoming vital in businesses as results of the recent financial scandals and business closures (Schneider, 2009). Being effective is a vital concern for all those interested parties in auditing such as the auditors or the banks' principal clients, and also includes (1) the Board of Directors (BOD) as well as the Audit and Governance Committee (AGC) where the internal auditors answered to; (2) top management where they ensure that the auditors' tasks encompass the

(C) Azam Abdelhakeem Khalid. Published in Asian Journal of Accounting Research. Published by Emerald Publishing Limited. This article is published under the Creative Commons Attribution (CC BY 4.0) licence. Anyone may reproduce, distribute, translate and create derivative works of this article (for both commercial and non-commercial purposes), subject to full attribution to the original publication and authors. The full terms of this licence may be seen at http://creativecommons.org/licences/by/4.0/legalcode

Received 7 October 2019 Revised 17 October 2019 7 November 2019

21 November 2019 8 February 2020

Accepted 14 February 2020

\section{uary 2020}


AJAR 5,1 main risks of business and (3) external auditors, where they are directly interested in the internal auditors' works (Mihret et al., 2010; Lenz and Hahn, 2015).

Accounting and Auditing Organization for Islamic Financial Institutions (AAOIFI, 2015) states that, the responsibilities of the AGC is to review internal audit in ensuring adequate supervision of those banks, which includes internal auditing is in place and that these controls are functioning properly. The AGC is also to monitor the execution of strategies set by the management. The AGC is to have adequate knowledge of the IFI's business and the supervised environment while making its vital inquiries regarding internal control system. It needs to acknowledge the findings of both external and internal auditors as well as assess the arising issues and problems. The committee is also to review the resources, capabilities, job scope, general task plans and the internal auditors' reporting hierarchy, assess the internal control mechanism's effectiveness with particular concentration on significant audit results, letters of external auditors and other vital reports from controlling authority together with the management's feedbacks. The AGC also functioned as a reviewer to the accounting practices and audit plan, particularly the audit assessment's nature and scope. This is specifically related to hazardous areas as well as the auditors' resources and capabilities; the cooperation between the IFIs' own auditors and the outside auditors, and ensures that the auditors' freedom and professional integrity are intact. The committee also has to consider the selection, resignation and removal of Shariah Supervisory Board (SSB) members, and the outside auditors and/or the head internal audit department (AAOIFI, 2015).

Generally, the various socioeconomic behaviors and economic objectives as well as the multiple policy recommendations and theoretical frameworks are results of an array of worldviews (Umer, 2000). A discourse on Islamic worldview can assist in clarifying the framework where the principles of Islamic accounting and reporting being established. All Muslims subscribed to the basis of Tawheed that is there is only one God, Allah swt. Here, the greatest being is Allah, where there is no other God but Him. He made the humans and established guidelines that govern them. As such, it is the goal of this research to examine the AGC role for internal Shariah auditing effectiveness among Bahrain's Islamic banks. The subsequent sections of this/the study are the following. The second section discusses Islamic worldview's literature review, the functions of AGC and subsequently the effectiveness of internal Shariah auditing. The third section presents the methodology of study. The fourth section presents the findings and discussions. The final section concludes and gives proposals for future study.

\section{Literature review \\ 2.1 Islamic worldview}

The worldview has a vital function in our everyday lives. In our every pursuit, worldview will have an influence on it. It is about how we perceive and comprehend the events happening around the world, particularly those related to religion, as well as political views and notions. In principal, it differs from the one of the Western's (Htay and Salman, 2013). Al-Attas (1978) states that for Islamic worldview, it is a "vision of reality and truth" (ra'yat al-Islam li alwujud). It is further interpreted by him that Islamic worldview is "a metaphysical survey of visible as well as the invisible worlds including the perspective of life as a whole, is not a worldview that is formed merely by the gathering together of various cultural objects, values and phenomena into artificial coherence". (p. 26).

Al-Attas (1978) states that Islam has always been about the way of living. The foundation of Islamic teaching is static. However, its "branches" such as finance, management and economics are flexible, and they change across time and situations. The obvious regulations and norms remain unchanged in accordance to al-Quran and Sunnah, while their values must be centered upon Islamic worldview, such as the notion of religion (ad-Din). Islamic 
worldview has two distinct notions, i.e. on Earth, and after death (judgment day). On the other hand, the perspectives of Western secularist (religion is unrelated to other pursuits) and materialistic worldview differ from Islam. As such, in accordance to Islamic-worldview, i.e. in terms of Islamic nature of reality (ontology), there are this physical world, and the hereafter (Judgment Day). The essential element of Islamic worldview is Tawhid (Unity of Allah) (Anuar et al., 2009; Chapra and Chapra, 1992), and everything else is just an extension to it, i.e. Khalifah (vicegerent), "Abd (slave of God), Justice, Nature, Falah and so on. In view that AlQuran is the principal reference of Islamic worldview, Islamic worldview is also known as Quranic worldview. The first element which is the basic and greatest essence for Muslims is Tawheed (Unity of Allah). Here, Allah is the One, He creates and owns the universe; Islam dictates a total yielding to Him in all our pursuits (Maali et al., 2006; Muwazir et al., 2006). From the perspective of Shariah, the unification concept of Allah is stressed on accountability, and this encompasses the bond with Allah, and bonds with other beings. Moreover, the notion about Allah can be expanded to financial, political and socio-economic relationships, as well as between the Islamic banks" management and the shareholders. As such, all IFIs' operations have consistency with the foundation and guidelines set by Islam. This is because these activities have an impact on the community (Ummah), the Muslims in particular.

Islamic worldview underlies anything in Islam corroborating the nature of Islam itself, which is comprehensive, all pervasive and inextricable from sacred and profane; creation and purpose (worship); knowledge and action; and life now and hereafter. In any Islamic disciplines of knowledge, the field of knowledge should be based on Islamic worldview and vision. Most of the time, the literature will refer to Islamic worldview, as the vision is directly derived from the Islamic worldview forming elements of the worldview itself. The involvements of Islamic worldview have constructed positive contribution to the independence of Shariah auditors. The code of ethical conduct that is in accordance to Quran and Tawheed values is a must for every Muslim. In Islamic teaching, there is dualresponsibility, one to Allah and the other is to other human beings; and they are the most perfect answer in achieving a quality audit for IFIs.

\subsection{Audit and Governance Committee (AGC)}

The creation of AGC varies in accordance to every IFI and the nation where it is formed. It is formed through nonexecutive directors. Meanwhile, the AGC committee's chairman will also be appointed by the BOD. The committee is given an adequate power to execute its responsibilities with freedom and integrity. The terms of the AGC members matched the BOD members. It has to consist of more than three persons, representing a balanced perspective and experience. Its members must be experts in the business, as well as the regulations and guidelines for them to be able to have adequate dealing with matters related to accounting and auditing. They must also have the understanding of Islamic laws, the Islamic products and services that apply these laws as well as the AAOIFI's rulings. In regard to the committee's meeting, BOD's consent must be obtained; where internal by-laws are prepared to monitor these meetings, and who must participate in these meetings but, without voting rights. The AGC's reports must be given to the BOD through the chairman, with a copy to the CEO. It is also suggested that the committee's chairman to report to the BOD's chairman on all major issues discussed during the previous meeting. The BOD must have discussions on AGC's work in accordance to the quarterly report. There is a new interest pertaining to Islamic banks' corporate governance, especially the AGC. This is because the committee encompasses professionals who are independent, knowledgeable and highly qualified. Therefore, an Islamic bank with competent board can improve the internal Shariah auditors' independence as they understand the market situation (Safieddine, 2009).

\section{Role of Audit and Governance Committee}


AJAR

5,1

84

Theoretically, in accordance to Islamic worldview, the role of AGC (also globally known as Audit Committee) is to help the BOD to undertake an impartial and independent supervision through these roles: (1) the integrity of the processing of financial statement is preserved; (2) protect the investors, shareholders and stakeholders' interest; (3) an effective AGC is able to provide added affirmation on the financial data given to the BOD and (4) an independent party to the relationship the IFI's senior managers and stakeholders. The vital role of ACG emerged due to its function of attaining the basic goals of the IFIs. This is done by providing better transparency and greater coverage of financial disclosures, hence strengthening the confidence in the IFI's compliance with Islamic laws (AAOIFI, 2015). There are proofs that show the positive link between independent auditors and audit committee. The positive link between the performance of internal Shariah auditors and AGC signifies that the committee will improve these auditors' performance. Teoh and Lim (1996) discovered that the establishment of audit committee strongly and positively affects auditors' independence. Meanwhile, Goodwin and Yeo (2001) found that audit committee that is effective will enhance internal auditors' roles. This is because it acts as an impartial party where internal auditors can raise issues that impact the management. However, the presence of a governance committee reduces aggressive financial reporting and is associated with a higher level of voluntary disclosure. Results from these few studies suggest that further research is necessary to understand and potentially enhance the effectiveness of the governance committee.

\subsection{Effectiveness of internal Shariah audit}

Institute of Internal Auditor (IIA) (2010) stated that the extent of the targeted goals being attained, in which includes quality is defined as effectiveness. Effectiveness has been defined by BNM (2011) as the target in ensuring the achievement of an in-house control system that is good and effective for the compliance of Shariah. Badara and Saidin (2013) mentioned several meanings of effectiveness. The study's definition of internal audit effectiveness as how well the goals are being attained. Most researchers agreed that when the outcome is parallel to the objective, the program can be considered effective (Ussahawanitchakit, 2012). As such, the definitions mentioned above signify that this paper may define effective Shariah auditing as the capability of those auditors in achieving the targeted goals of the IFIs. The past literature related to effective internal Shariah auditing had been reviewed and adapted. Past studies on this subject are such as by Ahmad et al. (2009); Arena and Azzone (2007); Badara and Saidin (2014); Endaya and Hanefah (2013); Mihret and Yismaw (2007). Conventionally, the internal auditors concentrate on financial matters' compliance, and functioned as the supervision mechanism for good in-house control (Alzeban, 2014). Nonetheless, there has been a significant improvement in the importance of Shariah auditing; and this involves the consultation of IFIs' Shariah compliance.

Alzeban (2014) furnished the proof on the perceived internal auditors' effectiveness in the public sector of Saudi Arabia. This study examined the contributions of internal audit department's size, competence, the connection between internal auditors' freedom, internal and external auditors, and the support level by management to the matter under investigation. The managers and internal auditors of the organizations provided the data for the study. The multiple regression method had been employed in examining the relationship between internal auditors' effectiveness, and five elements; which are the internal audit's department size, competence and independence, as well as external and internal auditors' relationship, and support given by the management. This study contribute to the existing Saudi Arabia internal auditing literature and its findings show that supportive management is the main element for the auditors' effectiveness. However, the study's findings may not be generalized to other developing nations of not having same 
oil reserves, nor developed nations of long history of commercialization, public institutions and certain type of governance within the organizations. Various researchers had tried measuring effectiveness from diverse views through the focus on internal audit's process, output and outcome. Mihret and Yismaw (2007) concentrated on process using a case study to show that an effective internal auditing is the outcome of four elements, which are quality of internal auditing, support by management, corporate setting and characteristics of the audited.

It had been discovered by Ahmad et al. (2009) that there are several elements that affect the effectiveness of internal Shariah auditors in the Malaysian government sector. Those factors are inadequate support and training, inadequate workers and the manager's negative response toward the auditors' suggested solutions. Additionally, an effective auditing is also related to the comprehension of the stakeholders' anticipation toward the organization's performance. It was discovered that internal auditors could effectively undertake their tasks whenever they comprehend the anticipations of the organization's BOD, CEO and management (Feizizadeh, 2012). An effective and professional internal Shariah auditor has these attributes. Those are the capability of aligning the internal Shariah audit's structure with the bank operation's dynamics, a strong connection between managerial capabilities in sustaining the needs and expectations of SSB and what is appropriate. Moreover, trainings, experience, education and professional certifications will also influence internal auditors' effectiveness (Al-Twaijry et al., 2003).

Another empirical study examined the relationship between three factors such as independence, competency and work performance with effective internal Shariah audit of IFIs in Bahrain (Khalid et al., 2017). The research found that competency and work performance in terms of engagement planning, performing engagement and communicating results of internal Shariah audit were positively related to internal Shariah audit effectiveness but independence does not significantly influence effective internal Shariah audit. This study argued that the insignificant relationship between independence and internal Shariah audit effectiveness is caused by the independence criteria such as the insufficient contribution of senior management support, reporting level and unrestricted access to all departments and employees to add value to the internal Shariah audit effectiveness (Khalid et al., 2017).

As such, auditors who are effective will help their organizations to attain the corporate goals; in which those banks must ensure that these auditors are efficient in value creation and effectiveness. From the literature review, no research had been conducted on exploring the function of ACG for internal Shariah auditing's effectiveness in Bahrain's Islamic banks.

\section{Research methodology}

In accordance to the review of past research, the researcher had developed the study's questionnaire while maintaining the flexibility in delving into emerging issues during the interviews. This is because it is imperative that an unstructured interview be conducted with the AGC members of the Islamic banks. The study had conducted interviews with both the internal auditors and AGC members as a sample and a part of internal corporate Shariah governance in Bahrain's Islamic banks. The guide on the interview is in accordance to this study's objective and literature review. The interview questions were mainly modified from previous research studies such as by Al-Twaijry et al., 2003; Arena and Azzone, 2007; Mihret and Yismaw, 2007. There was some degree of independence given to the respondents in explaining their experiences and views where sequenced questions and established specific answer segments were not followed. This study also examines the respondents' background and certification of certain respondents such as the AGC members (who are mostly GCC universities' academics) and the members of National Shariah Advisory Council. This study has particularly checked on the respondents' qualification by determining their bachelor

\section{Role of Audit and Governance Committee}


AJAR

5,1

86

degrees. The information related to their qualification was obtained through the Islamic banks' annual reports and websites. Meanwhile, the respondents were selected through convenience sampling.

The interview method was selected in view that AGC in the context of Bahrain's Islamic banks is yet to be examined by any research. As previously mentioned, this study examined the function of AGC. It is this study's objective of interpreting the internal Shariah auditors and AGC member' views in attaining an effective internal Shariah auditing. This study may decide from the three interview methods, i.e. semi-structured, structured and unstructured (Sekaran and Bougie, 2016). In exploring Shariah auditing, unstructured interview method had first been used by this study.

\section{Results and discussion}

In attempting to achieve the comprehension about AGC's function for an effective internal Shariah auditing, this study had conducted unstructured interviews with the respondents. It is obvious that from the data gained from the interviews and documents, there is a direct interaction and communication between Internal Shariah Department Head and the CEO instead of the Islamic bank's BOD. During the initial stage of the analysis on the independence of these auditors, this study established the organizational hierarchy of the auditors in their respective banks. As such, a review had been done on those banks' corporate structure. From this examination, it is obvious that the banks' corporate Shariah governance consisted of the auditors. This means, the auditors are directly connected to the SSB, AGC and $\mathrm{CEO}$. As such, the researcher had posed them questions in regard to the function of these auditors in Bahrain's Islamic banks. The interviews are deemed relevant in perceiving how effective the auditors are in maintaining their effectiveness.

The direct interaction between the board members and internal Shariah auditors will enhance the auditors' independence. Therefore, questions regarding their independence were posed to the Shariah Audit Department Head to establish their communication and interaction with the BOD. The AAOIFI (2015) mentioned that upon completion of such audit, a quarterly written report has to be sent to the BOD, with a copy each to the management and SSB. The IFI's organizational chart indicates that the BOD has not direct communication with the Internal Shariah Audit Department. The internal Shariah auditor mentioned that:

We do not have direct contact with the BODs. But, rather, we have a direct contact with the chief executive officer, SSB and AGC who can contact the BODs directly if necessary. Because we do not attend the BODs meetings, the SSB and CEO present our internal Shariah audit reports on behalf of our department. The communication between us and the BODs is limited to the following up of the decisions of the board only, and to sending a copy to the department of internal Shariah audit to enable them to monitor the implementation of decisions. And thus, the preparation of reports indicating the extent to which the various departments should implement recommendations and to clarify decisions to enable preparation of these reports for the chief executive officer to submit to the BODs.

The AGC concurred the statement. They indicated that:

It is not important for the BODs to communicate and consult the internal Shariah audit departments directly. The reason is that, we meet the BODs regularly, and it is our responsibility to raise the work of internal Shariah audit to the board.

As such, in ensuring the auditors' effectiveness, there should be a direct communication with the BOD. This communication provides the means for the auditors and BOD in keeping every party informed on the Masalahah (public interest) issues (AAOIFI, 2015). The auditors' effectiveness and subsequent authority will be enhanced through their subordination to the 
BOD. This will also give the needed support in executing the suggestions given by the auditors, and provide the BOD an effective mechanism to understand and review organizational activities (Yee et al., 2017).

Nonetheless, in ensuring the auditors' effectiveness, the hiring and dismissal of the auditors must be approved by the BOD. As such, the next question in establishing the effectiveness of the auditors is the identity of the individual responsible in appointing or removing the auditors. The internal Shariah auditors had been posed a question on this subject and the focus was on who are given the responsibility to make the decisions. This study found that in all the Islamic banks studied, the responsibility of appointing and removing an internal Shariah auditor falls on the AGC. A respondent mentioned that:

The internal Shariah auditor is appointed by an AGC, and the BODs confirmed the decision to appoint him. Then a copy of this decision is sent to the human resources department, and the director of human resources informs the Head of internal Shariah audit of his appointment. A copy of this appointment is then distributed to various departments and branches within the Islamic banks.

\section{Conclusion}

This study examines the function of AGC in ensuring an effective internal Shariah auditing. The study had employed the Islamic-worldview-based theory to examine this area of study among Bahrain's Islamic banks. The literature review conducted indicates there are limited studies on AGC, and effective internal Shariah auditing among Islamic banks. This study is an effort toward improving the number of studies on this area of study. It is also hoped that this study provides a greater understanding on effective internal Shariah auditors in Islamic banks, in which demand a distinct set of workforce.

In view of the roles of AGC on internal Shariah audit effectiveness, the current exploratory research contribute to enhance the limited knowledge about AGC by describing the practices of Bahraini Islamic banks in terms of composition, roles/duties and responsibilities and operations. This study also adds to the body literature of AGC effectiveness by identifying roles, duties and responsibilities of characterizing more active AGC and suggesting that these AGC could have a positive impact on internal Shariah audit effectiveness in Bahraini Islamic banks. Overall, this paper provides important insights for BOD's member can refer to AGC roles, duties and responsibilities to conduct a selfdiagnosis of current practice.

This paper proposes that in developing the conceptual framework for effective internal Shariah auditors (primary accountor), the Islamic-worldview-based theory may be utilized. In view of the AGC's position as the foremost oversighting authority in the IFIs, the auditors' effectiveness may directly be influenced by them. Thus, it is further proposed that internal Shariah auditor effectiveness is stronger at higher level of AGC. Additionally, more factors and/or secondary accountee variables of Islamic accountability theory can be added into this conceptual framework such as internal Shariah auditors' competence, internal audit scope, SSB and Shariah compliance's officers to name a few. However, external auditors may be considered as interviewees for the future study.

\section{References}

AAOIFI, A. (2015), Accounting, Auditing and Governance Standards for Islamic Financial Institutions, AAOIFI, Bahrain.

Ahmad, N., Othman, R., Othman, R. and Jusoff, K. (2009), "The effectiveness of internal audit in Malaysian public sector", Journal of Modern Accounting, Vol. 5 No. 9, p. 53.

Al-Attas, M.N. (1978), Istam and Secularism, Muslim Youth Movement of Malaysia, Kuala Lumpur.

\section{Role of Audit and Governance Committee}


AJAR 5,1

Al-Twaijry, A.A., Brierley, J.A. and Gwilliam, D.R. (2003), "The development of internal audit in Saudi Arabia: an institutional theory perspective", Critical Perspectives on Accounting, Vol. 14 No. 5, pp. 507-531.

Alzeban, A. and Gwilliam, D. (2014), "Factors affecting the internal audit effectiveness: a survey of the Saudi public sector", Journal of International Accounting, Auditing and Taxation, Vol. 23 No. 2, pp. 74-86.

Anuar, H.A., Sulaiman, M. and Ahmad, N.N.N. (2009). Some evidence of environmental reporting by Shariah compliant companies, International Journal of Economics, Management and Accounting, Vol. 17 No. 2, pp. 177-208.

Arena, M. and Azzone, G. (2007), "Internal audit departments: adoption and characteristics in Italian companies", International Journal of Auditing, Vol. 11 No. 2, pp. 91-114.

Badara, M.A.S. and Saidin, S.Z. (2013), "Antecedents of internal audit effectiveness: a moderating effect of effective audit committee at local government level in Nigeria", International Journal of Finance and Accounting, Vol. 2 No. 2, pp. 82-88.

Badara, M.A.S. and Saidin, S.Z. (2014), "Empirical evidence of antecedents of internal audit effectiveness from Nigerian perspective”, Middle-East Journal of Scientific Research, Vol. 19 No. 4, pp. 460-469.

BNM (2011), "Shariah governance framework for islamic financial institution (SGF)", available at: http://www.bnm.gov.my.

Chapra, M.U. (1992), Islam and the Economic Challenge (No. 17), International Institute of Islamic Thought (IIIT), Kuala Lumpur.

Endaya, K.A. and Hanefah, M.M. (2013), "Internal audit effectiveness: an approach proposition to develop the theoretical framework", Research Journal of Finance and Accounting, Vol. 4 No. 10, pp. 92-102.

Feizizadeh, A. (2012), "Strengthening internal audit effectiveness", Indian Journal of Science and Technology, Vol. 5 No. 5, pp. 2777-2778.

Goodwin, J. and Yeo, T.Y. (2001), "Two factors affecting internal audit independence and objectivity: evidence from Singapore", International Journal of Auditing, Vol. 5 No. 2, pp. 107-125.

Htay, S.N.N. and Salman, S.A. (2013), "Transaction cost theory, political theory and resource dependency theory in the light of unconventional aspect", IOSP Journal of Humanities and Social Science, Vol. 12 No. 5, pp. 89-96.

Khalid, A.A., Haron, H.H. and Masron, T.A. (2017), "Relationship between internal Shariah audit characteristics and its effectiveness", Humanomics, Vol. 33 No. 2, pp. 221-238.

Lenz, R. and Hahn, U. (2015), "A synthesis of empirical internal audit effectiveness literature pointing to new research opportunities", Managerial Auditing Journal, Vol. 30 No. 1, pp. 5-33.

Maali, B., Casson, P. and Napier, C. (2006), "Social reporting by Islamic banks", Abacus, Vol. 42 No. 2, pp. 266-289.

Mihret, D.G. and Wondim Yismaw, A. (2007), "Internal audit effectiveness: an ethiopian public sector case study", Managerial Auditing Journal, Vol. 22 No. 5, pp. 470-484.

Mihret, D.G., James, K. and Mula, J.M. (2010), "Antecedents and organisational performance implications of internal audit effectiveness: some propositions and research agenda", Pacific Accounting Review, Vol. 22 No. 3, pp. 224-252.

Muwazir, M.R., Muhamad, R. and Noordin, K. (2006), "Corporate social responsibility disclosure: a tawhidic approach”, Jurnal Syariah, Vol. 14 No. 1, pp. 125-142.

Rahman, A.R.A. and Rahim, A. (2011), "Enhancing the integrity of islamic financial institutions in Malaysia: the case for the shariah audit framework", ISRA international journal of Islamic finance, Vol. 3 No. 1, pp. 135-147.

Safieddine, A. (2009), "Islamic financial institutions and corporate governance: new insights for agency theory", Corporate Governance: An International Review, Vol. 17 No. 2, pp. 142-158. 
Schneider, A. (2009), "The nature, impact and facilitation of external auditor reliance on internal auditing", Academy of Accounting and Financial Studies Journal, Vol. 13 No. 4, p. 41.

Sekaran, U. and Bougie, R. (2016), Research Methods for Business: A Skill Building Approach, John Wiley and Sons.

Teoh, H.Y. and Lim, C.C. (1996), "An empirical study of the effects of audit committees, disclosure of nonaudit fees, and other issues on audit independence: Malaysian evidence", Journal of International Accounting, Auditing and Taxation, Vol. 5 No. 2, pp. 231-248.

Umer Chapra, M. (2000), The Future of Economics: An Islamic Perspective, Islamic Foundation, Leicester.

Ussahawanitchakit, P. (2012), "Audit independence of tax auditors in Thailand: roles of ethical orientation, professional responsibility, stakeholder pressure, and audit experience", Journal of the Academy of Business and Economics, Vol. 12 No. 1, pp. 1-11.

Yee, C.S., Sujan, A., James, K. and Leung, J.K. (2017), "Perceptions of Singaporean internal audit customers regarding the role and effectiveness of internal audit”, $A J B A$, Vol. 1 No. 2, pp. 147-174.

\section{Further reading}

Gaballa, A.S. and Ning, Z. (2011), "An analytical study of the effects of experience on the performance of the external auditor", International Conference on Business and Economics Research, Kuala Lumpur, Vol. 1, pp. 169-173.

Haneef, M.A.M. (1997), "Islam, the islamic worldview and islamic economics", IIUM Journal of Economics and Management, Vol. 5 No. 1, pp. 39-66.

Ibrahim, S.H.B.M., Wirman, A., Alrazi, B., Nor, M.N.M. and Pramono, S. (2006), "Alternative disclosure and performance measures for Islamic banks, international Islamic university Malaysia”, 2nd International Conference on Administrative Sciences, pp. 19-21.

Murtuza, A. and Abdallah, W. (2007), "Islamic muhtasib and American CPAs: a comparative study of institutions meant to protect public interest", Journal of Accounting, Business and Management, Vol. 14.

Soobaroyen, T., Ntim, C.G., Broad, M.J., Agrizzi, D. and Vithana, K. (2019), "Exploring the oversight of risk management in UK higher education institutions: the case of audit committees", Accounting Forum, Routledge, pp. 1-22.

Sulaiman, M. (2005), Islamic Corporate Reporting: Between the Desirable and the Desired, International Islamic University Malaysia, Gombak.

\section{Corresponding author}

Azam Abdelhakeem Khalid can be contacted at: azamabdelhakeem@gmail.com

For instructions on how to order reprints of this article, please visit our website:

www.emeraldgrouppublishing.com/licensing/reprints.htm

Or contact us for further details: permissions@emeraldinsight.com 